\title{
SUMARIO CONTENTS
}

Struttura e finanziamento del settore post laurea in brasile nel contesto dello sviluppo del servizio pubblico dell'educazione

7 The structure and financing of postgraduation in brazil in the context of development of the public service of education

DOI: www.dx.doi.org/10.14409/rr.v2i1.4628

\section{Alexandre Godoy Dotta}

Mecanismos de acceso a la vivienda en américa latina. Algunos casos

Housing access mechanisms in latin america. A few cases

DOI: www.dx.doi.org/10.14409/rr.v2i1.4629

\section{Analía Antik}

Vinculación de la administración pública a los precedentes administrativos y judiciales: mecanismos de tutela igualitaria de los derechos sociales

39 Binding Public Administration to administrative and judicial precedentes: mechanisms of equal protection of social rights

DOI: www.dx.doi.org/10.14409/rr.v2i1.4633

\section{Daniel Wunder Hachem}

La nueva ley anticorrupción brasileña: aspectos controvertidos y los mecanismos de responsabilización de las personas jurídicas

71 The new brazilian anti-corruption act: controversial aspects and penalty mechanisms of private entities

DOI: www.dx.doi.org/10.14409/rr.v2i1.4630

Emerson Gabardo • Gabriel Morettini e Castella 


\section{Políticas públicas, inclusão social e desenvolvimento democrático Public policies, social inclusion and democratic development \\ DOI: www.dx.doi.org/10.14409/rr.v2i1.4631 \\ Eneida Desiree Salgado \\ Planejamento do uso da terra e planejamento ambiental e transporte: como alcançar níveis sustentáveis de planejamento \\ 101 \\ Planning of land use and environmental planning and transportation: how to achieve sus- \\ tainable levels of planning \\ DOI: www.dx.doi.org/10.14409/rr.v2i1.4632}

\section{Filippo Colapinto}

Storiografia giuridica e autonomie locali nell'italia contemporanea

119

Juridical historiography and local autonomies in the italy's contemporary age

DOl: www.dx.doi.org/10.14409/rr.v2i1.4634

\section{Gianfranco Stanco}

La cláusula del estado social y los derechos fundamentales sociales

155

The clause of welfare state and the fundamental social rights

DOI: www.dx.doi.org/10.14409/rr.v2i1.4635

\section{Jaime Rodríguez-Arana Muñoz}

La reforma de la administración pública local para la tutela de los derechos

185

fundamentales en el siglo xxi

Local public administration reform to the protection of fundamental rights in the xxi century

DOI: www.dx.doi.org/10.14409/rr.v2i1.4636

Justo José Reyna

La corruzione con apparenza lecita

243

The corruption that seems to be legal

DOI: www.dx.doi.org/10.14409/rr.v2i1.4637

\section{Luiz Alberto Blanchet}

Compliance: una perspectiva desde la ley brasileña n $12.846 / 2013^{*}$

257

Compliance: a perspective from the brazilian law no 12.846/2013

DOI: www.dx.doi.org/10.14409/rr.v2i1.4638

\section{Marcia Carla Pereira Ribeiro • Patrícia Dittrich Ferreira Diniz}

El renovado derecho administrativo, a la luz del control de convencionalidad

283

The renewed administrative law in light of conventionality control

DOI: www.dx.doi.org/10.14409/rr.v2i1.4639

\section{Raquel Cynthia Alianak}

